\title{
A Comparative Study of Distribution of Protein and Cholesterol in Various Fractions of Human Semen from Infertile and Fertile Subjects
}

\author{
Vickram Sundaram, MS Srinivas, Kamini A Rao, M Ramesh Pathy, TB Sridharan
}

\section{ABSTRACT}

Aim: To elucidate the concentration of the protein and cholesterol in different fractions of human semen from different infertile categories and comparing them with the fertile group.

Materials and methods: The human semen was collected from different infertile categories including oligoasthenospermia, asthenospermia, azoospermia, normospermia, oligospermia and fertile group. Immediately after collection, the semen analysis was done as per WHO standard protocols. After that, the semen was centrifuged to get the different fractions. Four main fractions were obtained, (1) spermatozoa, (2) debris or material that precipitates at $12 \mathrm{~K} \mathrm{rpm}$ for 10 minutes, (3) prostasomes which was precipitated at $20 \mathrm{~K}$ rpm for 120 minutes, (4) seminal plasma. The protein concentration was done by Lowry's method and cholesterol was estimated by diagnostic kit.

Results: Sodium dodecyl sulfate-polyacrylamide gel electrophoresis (SDS PAGE) was run for all the categories of semen samples for their seminal plasma and the fertility associated protein was identified. A significant difference was found in the concentration of proteins in all subfractions when compared between control and infertile categories. Almost $86 \%$ of the protein was recovered from soluble fraction. In case of azoospermia, the protein content was very low when compared with fertile group. Seminal plasma proteins were visualized by silver staining. The molecular weight of the protein bands were ranging from 6.5 to $205 \mathrm{kDa}$. The band with molecular weight around $55 \mathrm{kDa}$ was found to be missing in case of oligoasthenospermia. This particular protein is said to be fertility associated protein. The content of cholesterol for different subfraction of the human semen samples from infertile and fertile samples was compared. A wide range of cholesterol was recovered from prostasomes, that too purified.

Conclusion: A thrive study have to be done in all the subfractions of the semen irrespective of the category of samples to know the exact function of the each subfractions in terms of protein and cholesterol distribution.

Keywords: Seminal plasma, Prostasomes, Spermatozoa, Infertility, Cholesterol.

How to cite this article: Sundaram V, Srinivas MS, Rao KA, Pathy MR, Sridharan TB. A Comparative Study of Distribution of Protein and Cholesterol in Various Fractions of Human Semen from Infertile and Fertile Subjects. Int J Infertility Fetal Med 2012;3(3):78-82.

Source of support: Nil

Conflict of interest: None declared

Date of Received: 18-09-12

Date of Acceptance: 19-09-12

Date of Publication: September 2012

\section{INTRODUCTION}

Human male infertility is found to be the stressful issue to both the couple as well as the families. Under these circumstances World Health Organization has announced human male infertility as the global problem. ${ }^{1}$ Human semen consists of seminal plasma and spermatozoa and is secreted by various glands like prostate, seminal vesicles, testes and small accessory glands. Reproductive fluids (semen in humans) of different mammals exposed that the existence of multilamellar vesicles and thought to contain much protein, ions and high cholesterol to phospholipid ratio. This type of seminal vesicle was firs isolated from the human semen and found to have prostatic origin. ${ }^{2}$ The protein concentration in human semen in various fractions is very important for maintaining the constant motility and well morphology. Human prostasome is one of the main fractions of the semen which was isolated when centrifuging the semen sample for 120 minutes. The prostasome was rich in protein and cholesterol. Even though for the fertilization only the mature spermatozoa is required, but usually the other parts include seminal plasma, prostasome and the debris present in semen also found to have proper role to fertilize the ovum. ${ }^{3}$ The protein concentration in the semen is very high because of the seminal plasma without spermatozoa. The function of the seminal plasma is not well understood. The seminal plasma in semen is very much required for the liquefaction immediately after the ejaculation. When the properties of the seminal plasma were reduced, there will be delay in coagulation or liquefaction of the semen. The very important function of the seminal plasma was its buffering property, is much useful in neutralizing acidic nature of the female reproductive tract. ${ }^{4}$ Seminal plasma contains proteins, carbohydrates, cholesterol and various metals. Seminal plasma is the highest fraction out of all the semen fractions that contains about $70 \%$ of the protein concentration. Spermatozoa are very much essential for the ovum to fertilize. Spermatozoa are highly dedicated cells that contribute the genetic paternal genetic complement in the reproductive process. The transcriptional and translational machinery of the spermatozoa to produce new proteins is limited. The concentration or the amount of protein present in the spermatozoa is also very important for the proper 
functioning of the semen..$^{5}$ Almost 30 to $50 \%$ of infertility in the couples is due to male factor and it is due to the deficiency in the sperm quality and quantity. The quality of the sperm mainly represents the amount or concentration of the proteins that helps in the motility of the sperm cell. ${ }^{6}$ The amount of proteins, lipids, cholesterol and even many other parts in the seminal plasma and their functions in the fertilization were not properly known. In this research, human infertile as well as fertile samples were collected and immediately the microscopic and macroscopic analysis were done and recorded. Human semen is fractionated into seminal plasma, spermatozoa, prostasome, their protein concentration were done using Lowry's method. The concentration of the protein, cholesterol and lipids were compared between the various infertile categories and fertile category.

\section{MATERIALS AND METHODS}

\section{Semen Population}

Fifty-two semen samples were collected from the infertile persons, including oligoasthenospermia $(\mathrm{n}=10)$, asthenospermia ( $n=10)$, azoospermia $(n=6)$, normospermia $(\mathrm{n}=10)$, oligospermia $(\mathrm{n}=8)$ and fertile samples $(\mathrm{n}=8)$ for this research.

\section{Research Ethics}

This research study is basically a part of a major research project, for which the human ethical approval and clearance has been obtained from institutional ethical committee.

\section{Materials Used}

All the chemicals needed for sodium dodecyl sulfate polyacrylamide gel electrophoresis (SDS PAGE) were purchased from Hi-media. Molecular weight marker proteins for electrophoresis were purchased from GeNei, Bangalore, India. Sephadex G-75 was purchased from Sigma, USA.

\section{Fractionation and Purification of Human Infertile and Fertile Semen Samples}

Human infertile samples were collected from the patients with the age difference between 27 and 40, and the fertile samples ranging from 18 to 35 . Totally, 44 different infertile samples and eight control samples were examined. After the semen evaluation was over, the semen was centrifuged at 8,000 rpm for 10 minutes to obtain the raw spermatozoa. The supernatant was transferred to the other tube and again centrifuged at 12,000 rpm for 20 minutes to get the pellet which was analyzed later. The remaining supernatant was transferred and centrifuged at $80 \mathrm{~K}$ rpm for continuous 120 minutes. The pellet formed now is raw prostasome and the supernatant is seminal plasma. The spermatozoa and prostasome pellet were further purified by the protocol described by Arientia et $\mathrm{al}^{7}$ with some modifications which was standardized in our laboratory. Spermatozoa samples were pendant in $180 \mathrm{mmol} / \mathrm{l} \mathrm{NaCl}$ and $50 \mathrm{mmol} / \mathrm{l}$ of Tris base at $\mathrm{pH}$ 7.6. The samples were washed thrice with freshly prepared buffer. Purification of spermatozoa was done by layering 50\% density gradient material. The spermatozoa samples were centrifuged at 5,000 rpm for 20 minutes and then the spermatozoa were collected at the bottom of the tube. Prostasome were purified by passing the raw prostasome in Sephadex G-75 column ${ }^{7}$ with some modifications done. The samples were washed twice in the freshly prepared $180 \mathrm{mmol} / \mathrm{l} \mathrm{NaCl}$ and $50 \mathrm{mmol} / \mathrm{l}$ of Tris base at $\mathrm{pH}$ 7.6. The purified prostasome were collected at the bottom of the tube with void volume. The samples were centrifuged at 20,000 rpm for 120 minutes.

\section{Protein and Cholesterol Analyses}

Protein estimation was carried out by the protocol followed by, ${ }^{8}$ and the cholesterol was estimated by using the biodiagnostic kit.

\section{Sample Processing for SDS PAGE}

The stored samples were taken and processed for protein analysis by SDS PAGE. Equal amount of gel loading dye (2.5 ml of $4 \times$ Tris Cl-SDS at pH 6.8, $2 \mathrm{ml}$ of glycerol, $0.4 \mathrm{gm}$ of SDS, $200 \mu \mathrm{l}$ of 2-mercaptoethanol, $0.1 \mathrm{gm}$ of bromophenol blue, dissolved in $10 \mathrm{ml}$ of Milli Q water) was added, mixed and boiled at $100^{\circ} \mathrm{C}$ hot water bath for 10 minutes. Then the SDS-PAGE gel was prepared. (Separating gel was prepared by mixing $2.5 \mathrm{ml}$ of $30 \%$ acrylamide and $\mathrm{N}, \mathrm{N}$-methyl bis-acrylamide, $1.8 \mathrm{ml}$ of $4 \times$ Tris $\mathrm{Cl}$ at pH 8.8, $3.05 \mathrm{ml}$ of Milli Q water, $80 \mu \mathrm{l}$ of freshly prepared APS and $40 \mu \mathrm{l}$ of TEMED. Mix it well and poured in PAGE plates. It was allowed to polymerize for 30 minutes. Stacking gel was prepared by mixing $0.65 \mathrm{ml}$ of $30 \%$ acrylamide and N,N-methyl bis-acrylamide, $1.25 \mathrm{ml}$ of $4 \times$ Tris Cl-SDS buffer at pH 6.8, $3.05 \mathrm{ml}$ of Milli Q water, $40 \mu \mathrm{l}$ of freshly prepared APS and $25 \mu \mathrm{l}$ of TEMED. It was poured above the separating gel and allowed to polymerize 20 minutes. The comb was inserted into the SDS plates without disturbing the gel volatility). This set up was allowed for 1 hour. The set up was made ready to load the sample, after loading allow the gel to run in the buffer for 3 hours or until it reaches the bottom. The molecular weight was estimated by using the protein low-molecular as well as high-molecular weight protein marker. After 
electrophoresis, gels were stained with silver stain by methanol method.

\section{Data Analysis}

The concentration of protein and cholesterol in different fractions were examined for all the infertile and fertile categories. First, the semen samples were evaluated and the values were represented as mean \pm standard error and then the concentrations in $\mathrm{mg} / \mathrm{ml}$ were evaluated. The gel was analyzed to determine the molecular weight of the protein. Graph pad prism version 1.1 was used as a statistical tool in this research.

\section{RESULTS AND DISCUSSION}

The infertile samples were collected from the patients and immediately the semen is evaluated according to the standard protocol followed by World Health Organization (WHO, 1992). The fertile (control) samples were collected in fact from healthy persons. After collecting the samples, the initial microscopic and macroscopic parameters include volume, $\mathrm{pH}$, sperm count, total motility, and normal morphology were evaluated and then recorded. The values which we got were in correlation with the results of Shunetar ${ }^{9}$ the average sperm concentration for fertile group was found to be 107.1 millions/ml and whereas in any kind of infertile samples it was deeply low except normospermia samples.

Volume and $\mathrm{pH}$ of all the samples including fertile group remains to be same, when comparison was done between fertile and various infertile categories, fertile group shows mild increase in terms of volume of the sample ejaculated, whereas in case of $\mathrm{pH}$, the values lies between 7.2 and 8.0 as clearly shown in Table 1.

Once the semen parameters were evaluated, the next step in this research is to estimate the protein concentration and then to run to SDS PAGE to find the protein bands and its molecular weight. Comparison was done between all categories of infertile and fertile samples in terms of protein concentration and molecular weight of protein bands. The fractions obtained in this research were spermatozoa, spermatozoa purified, debris or the material precipitating at $12,000 \mathrm{rpm}$, prostasome, prostasome purified and the seminal plasma.

The protein concentration was done by Lowry's method for all the subfractions. Seminal plasma or the soluble fraction contributes almost $86 \%$ for the overall protein content of the ejaculated semen. Spermatozoa contribute around $6 \%$ as recovered from the whole semen. A very little bit amount of protein content was recovered from prostasomes. When purified with the in Sephadex G-75 column, the protein recovery was increased by $29 \%$. The literature reveals that in terms of protein, the spermatozoa and prostasome were same. ${ }^{10}$ The concentration of protein is twice higher in spermatozoa than prostasomes (Table 2), in case of the raw material. In case of azoospermia, the concentration of protein was found to be nil in all the subfractions of the ejaculated semen. On an average the seminal plasma concentration was found to be $19 \mathrm{mg} / \mathrm{ml}$. A higher level significant difference was found in the case of protein concentration, when compared between control and all the other categories of infertile sample. No significant

\begin{tabular}{|c|c|c|c|c|c|c|}
\hline \multirow{2}{*}{$\begin{array}{l}\text { Semen } \\
\text { parameters }\end{array}$} & \multicolumn{5}{|c|}{ Infertile groups } & \multirow{2}{*}{$\begin{array}{l}\text { Fertile (control } \\
\text { group) }\end{array}$} \\
\hline & $\begin{array}{l}\text { Oligoastheno- } \\
\text { spermia }\end{array}$ & $\begin{array}{l}\text { Astheno- } \\
\text { spermia }\end{array}$ & $\begin{array}{l}\text { Azoo- } \\
\text { spermia }\end{array}$ & $\begin{array}{l}\text { Normo- } \\
\text { spermia }\end{array}$ & $\begin{array}{l}\text { Oligo- } \\
\text { spermia }\end{array}$ & \\
\hline Volume & $2.49 \pm 0.43$ & $1.89 \pm 0.16$ & $2.16 \pm 0.42$ & $2.44 \pm 0.25$ & $2.06 \pm 0.15$ & $3.075 \pm 0.244$ \\
\hline $\begin{array}{l}\mathrm{pH} \\
\text { Sperm count }\end{array}$ & $7.7 \pm 0.08$ & $7.5 \pm 0.07$ & $7.41 \pm 0.11$ & $7.58 \pm 0.04$ & $7.78 \pm 0.11$ & $7.65 \pm 0.096$ \\
\hline $\begin{array}{l}\text { (millions/ml) } \\
\text { Total }\end{array}$ & $9.6 \pm 1.7$ & $44.40 \pm 3.75$ & 0.00 & $92.5 \pm 15.5^{\#}$ & $9.98 \pm 1.74$ & $107.1 \pm 13.2$ \\
\hline $\begin{array}{l}\text { motility (\%) } \\
\text { Rapid }\end{array}$ & $16.56 \pm 3.5^{\neq}$ & $36.07 \pm 4.99^{€}$ & $0.00^{€}$ & $70.02 \pm 3$ & $37.34 \pm 2.7^{€}$ & $65.61 \pm 6.34$ \\
\hline $\begin{array}{l}\text { progressive (\%) } \\
\text { Normal }\end{array}$ & $1.88 \pm 0.918^{\ell}$ & $5.80 \pm 1.02^{\ell}$ & $0.00^{\ell}$ & $17.04 \pm 2^{\ell}$ & $28 \pm 5.14$ & $29.01 \pm 2.684$ \\
\hline $\begin{array}{l}\text { morphology (\%) } \\
\text { Hypo-osmotic }\end{array}$ & $9.70 \pm 2.24^{\Delta}$ & $18.9 \pm 0.729$ & $0.00^{\Delta}$ & $25.3 \pm 1.1^{\Delta}$ & $34.7 \pm 2.9^{\Delta}$ & $17.04 \pm 1.50$ \\
\hline swelling (\%) & $16.3 \pm 4.13$ & $39.9 \pm 3.075$ & 0.00 & $77.1 \pm 2.84$ & $25 \pm 3.16$ & $79.25 \pm 3.331$ \\
\hline
\end{tabular}

Scores represented as mean \pm standard error mean. ${ }^{*} p<0.05$ is not significant, when the values of sperm concentration were compared to control in normospermia infertile group and the t-value was found to be 1.075 ; $\epsilon_{\mathrm{p}}<0.0001$ is not significant, when the values of total motility was compared between control and infertile groups done by using post hoc test; ${ }^{\neq} p<0.0001$ is found to be significant with three star, when the total motility in \% is compared with control (fertile group). ${ }^{\Delta} \mathrm{p}<0.05$ by using one-way ANOVA followed by post hoc test, when values were compared with control fertile group; ${ }^{l} p<0.001$ by using one way analysis of variance followed by post hoc test, when the values of infertile groups were compared with control group. No significant difference was found in case of volume and $\mathrm{pH}$ in all the categories of semen samples 
Table 2: Distribution of protein in various subfractions of fertile and infertile categories

\begin{tabular}{lcccccrr}
$\begin{array}{l}\text { Sample } \\
\text { categories }\end{array}$ & $\begin{array}{c}\text { Whole } \\
\text { semen }\end{array}$ & $\begin{array}{c}\text { Sperm- } \\
\text { atozoa (raw) }\end{array}$ & $\begin{array}{c}\text { Spermatozoa } \\
\text { (purified) }\end{array}$ & $\begin{array}{c}\text { Debris } \\
12 \mathrm{~K} \mathrm{rpm}\end{array}$ & $\begin{array}{c}\text { Prostasomes } \\
\text { (raw) }\end{array}$ & $\begin{array}{c}\text { Prostasomes } \\
\text { (purified) }\end{array}$ & $\begin{array}{c}\text { Seminal } \\
\text { plasma }\end{array}$ \\
\hline Oligoasthenospermia & $32 \pm 7.4$ & $3.1 \pm 1.2$ & $0.3 \pm 0.1$ & $1.2 \pm 0.6$ & $1.4 \pm 0.5$ & $0.4 \pm 0.1$ & $26.2 \pm 9.6$ \\
Asthenospermia & $42 \pm 8.6$ & $4.2 \pm 1.5$ & $0.3 \pm 0.1$ & $1.3 \pm 0.6$ & $1.2 \pm 0.3$ & $0.5 \pm 0.1$ & $35.6 \pm 7.7$ \\
Azoospermia & $20.5 \pm 2.3$ & Nil & Nil & 0.1 & Nil & Nil & $19 \pm 7.2$ \\
Normospermia & $60.7 \pm 12.2$ & $5.8 \pm 1.5$ & $0.8 \pm 0.1$ & $1.3 \pm 0.3$ & $1.6 \pm 0.5$ & $0.9 \pm 0.4$ & $51.4 \pm 8.8$ \\
Oligospermia & $35.4 \pm 7.8$ & $3.2 \pm 1.2$ & $0.4 \pm 0.05$ & $1.1 \pm 0.6$ & $1.2 \pm 0.5$ & $0.4 \pm 0.04$ & $30.1 \pm 12.1$ \\
Control & $63.4 \pm 13.2$ & $6.6 \pm 1.6$ & $1.1 \pm 0.5$ & $2.1 \pm 0.7$ & $2.5 \pm 0.6$ & $0.9 \pm 0.05$ & $53.2 \pm 14.2$ \\
\hline
\end{tabular}

Protein concentration was expressed in terms of $\mathrm{mg} / \mathrm{ml}$. All the values were expressed with mean $\pm \mathrm{SD}$

difference was found, when compared between control and normospermia (Fig. 1).

In case of cholesterol, the total content was much in prostasomes than in seminal plasma. The total content of protein and cholesterol is inversely proportional, that is, the protein content is rich in seminal plasma whereas cholesterol is rich in prostasomes (Fig. 2).

The proteins of the seminal plasma fractions were examined by SDS PAGE gel electrophoresis. Figure 3 shows the pattern of seminal plasma proteins of all categories of fertile and infertile samples. The pattern was slightly different which was shown in the literature. ${ }^{10}$ Protein fractions were compared with the marker proteins by calculating RF values according to the method recommended. ${ }^{11}$ Twenty-three bands were visible in the case of control sample. The molecular weight of the protein bands was visible between 10 and $205 \mathrm{kDa}$ (see Fig. 3). The proteins below molecular weight $43 \mathrm{kDa}$ were found to be prominent in this research. In the study ${ }^{12}$ the molecular weight below $66 \mathrm{kDa}$ were found to be prominent. The protein band with $205 \mathrm{kDa}$ band is almost missing in all the categories of the infertile samples. In infertile categories, the 17 band $^{13}$ were visible and their molecular weight was ranging from 29 to $205 \mathrm{kDa}$. The protein band with molecular weight around $56 \mathrm{kDa}$ is missing in the case of oligoasthenospermia and in azoospermia category of infertile samples. This particular band from the literature reveals that it is associated with fertility. ${ }^{14}$ The protein content of the band with molecular weight $66 \mathrm{kDa}$ is higher in case of normospermia ${ }^{15}$ than any other category.

\section{CONCLUSION}

Comparison of the semen parameter evaluation was done and found higher level significant difference in all the parameters when compared between fertile and infertile samples. Volume and $\mathrm{pH}$ shows a low level significant difference when compared. The protein content was found to be even in case of control and normospermia samples. Almost $86 \%$ of protein content was recovered from soluble fraction or seminal plasma and it is controversy cholesterol was bound to the prostasomes. So, it is known that protein

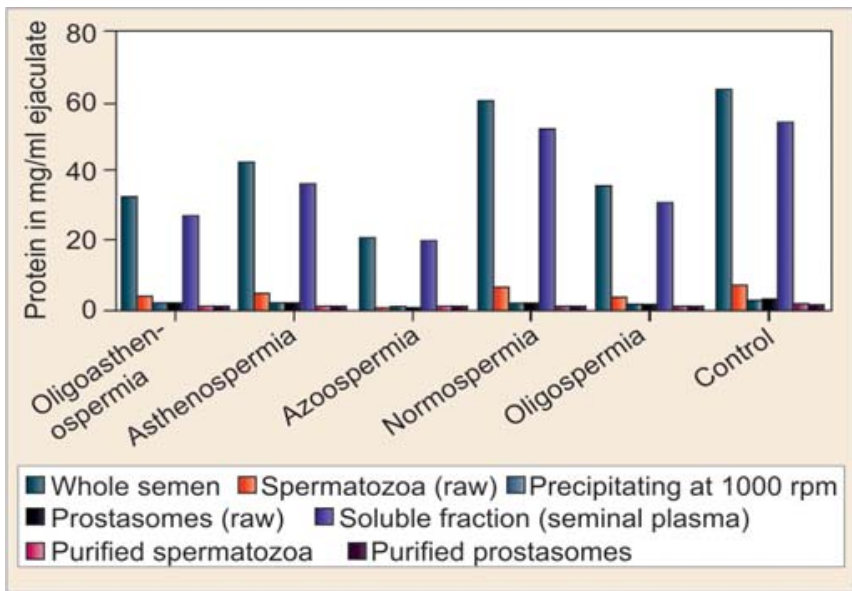

Fig. 1: Comparison of distribution of protein in various fraction of different category of human semen samples

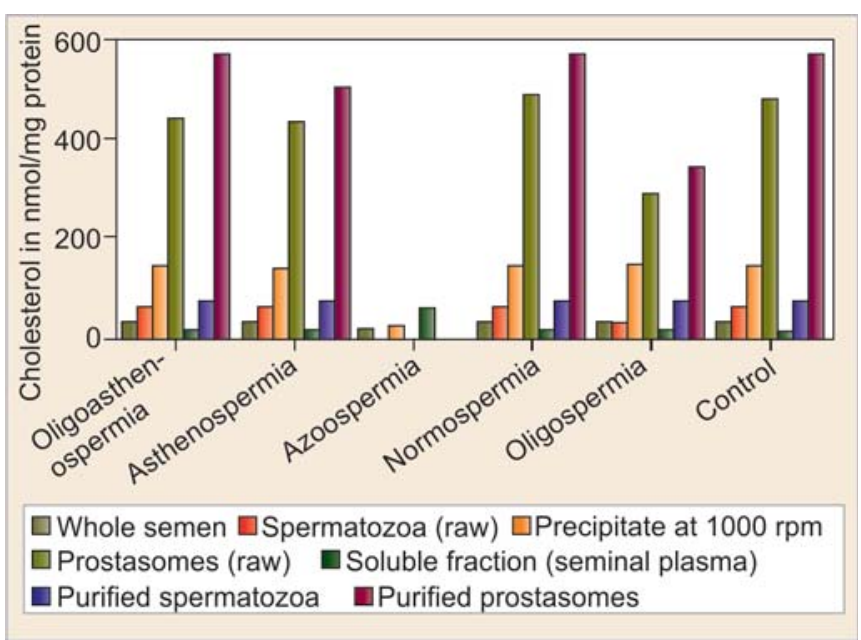

Fig. 2: Comparison of distribution of cholesterol in various fraction of different category of human semen samples

is soluble fraction bounded and cholesterol is prostasome bounded in human semen. In azoospermia samples, the protein content was very less when compared to any other category of human semen samples. When purified the raw prostasome, the recovery of the protein content was found to be higher and when purified the spermatozoa fraction the yield was same. When SDS PAGE was done for the seminal plasma samples of different categories of semen samples, 27 bands were found and some bands were missing in infertile samples. The particular bands were said to be 


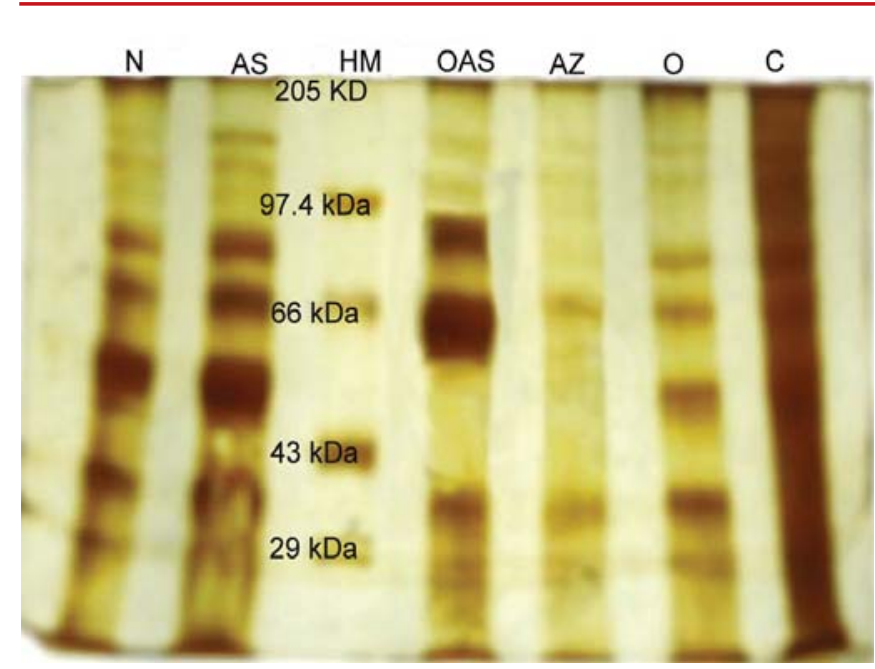

Fig. 3: Comparison of human seminal plasma proteins with fertile and infertile categories (N: Normospermia; AS: Asthenospermia, OAS: Oligoasthenospermia; HM: High molecular weight; AZ: Azoospermia; O: Oligospermia; C: Control)

the fertility associated proteins. Our further research will be focused on the identification of a protein marker fertility associated proteins for human semen to enhance the fertility.

\section{REFERENCES}

1. George K, Kamanth MS. Infertility and age: A review. J Hum Reproductive Sci 2010;3(3):121-23.

2. Ronquist G, Brody I. The prostasome: Its secretion and function in man. Biochem Biophys Acta 1985;822:203-18.

3. Mann T, Lutwak-Mann C. General feature of the seminal plasma. In: Mann T, Lutwak-Mann C, (Eds). Male reproductive function and semen: Themes and trends in physiology, biochemistry and investigative andrology, New York: Springer 1981;28-33.

4. Mann T, Lutwak-Mann C (Eds). Male reproductive functions and semen. Berlin: Springer, 1981.

5. Millette CF. Spermatozoa. In: Knobil E, Neill JD (Eds). Encyclopaedia of reproduction, San Diego: Academic Press 1998;586-96.

6. Isidori AM, Pozza C, Gianfrilli D, Isidori A. Medical treatment to improve sperm quality. Reprod Biomed Online 2006;12: 704-14.

7. Arientia G, Saccardib C, Carlinia E, Verdacchi R, Palmerini CA. Distribution of lipid and protein in human semen fractions. Clinica Chimica Acta 1999;289:111-20.

8. Lowry OH, Rosebrough NJ, Farr AL, Randall RJ. Protein measurement with the Folin Phenol reagent. J Biol Chem 1951; 193:265-75.
9. Shun T, Shulman S. Immunolectrophoretic analysis of human seminal plasma fractions after fractionation by various methods. Int J Fertil 1971;16:87-94.

10. Horrocks LA. The alk-1-enyl group content of mammalian myelin phosphoglycerides by quantitative two-dimensional thin layer chromatography. J Lipid Res 1968;9:469-72.

11. Fabiani R. Functional and biochemical characteristics of human prostasomes. Minireview based on a doctoral thesis. Ups J Med Sci 1994;99:73-111.

12. Jobim MIM, Oberst ER, Salbego CG, Wald VB, Horn AP, Mattos RC. BSP A1/A2-like proteins in ramseminal plasma. Theriogenology 2005;63:2053-62.

13. Hames BD. One-dimensional polyacrylamide gel electrophoresis. In: Hames BD, Rickwood D (Eds). Gel electrophoresis of proteins: A Practical Approach (2nd ed). Oxford University Press, Oxford 1990;4-17.

14. Calvete JJ, Mann K, Schafer W, Sanz L, Reinert M, Nessau S, et al. Amino acid sequence of HSP-1, a major protein of stallion seminal plasma: Effect of glycosylation on its heparin- and gelatin-binding capabilities. Biochem J 1995;310:615-22.

15. Poulos A, White IG. The phospholipid composition of human spermatozoa and seminalplasma. J Reprod Fertil 1973;53: 265-72.

\section{ABOUT THE AUTHORS}

\section{Vickram Sundaram}

Research Associate, Department of Industrial Biotechnology, SBST VIT University, Vellore, Tamil Nadu, India

\section{MS Srinivas}

Scientific Director, Department of Embryology, Bangalore Assisted Conception Center, Bengaluru, Karnataka, India

\section{Kamini A Rao}

Medical Director, Department of Assisted Reproduction, Bangalore Assisted Conception Center, Bengaluru, Karnataka, India

\section{Ramesh Pathy}

Associate Professor, Department of Industrial Biotechnology, SBST VIT University, Vellore, Tamil Nadu, India

\section{TB Sridharan (Corresponding Author)}

Associate Professor, Department of Industrial Biotechnology, SBST VIT University, Vellore, Tamil Nadu, India, e-mail: tbsridharan@vit.ac.in 